\title{
PROPRIETARY ESTOPPEL: AN ITALIAN CASE LAW PERSPECTIVE
}

\section{PROPRIETARY ESTOPPEL: UN'ANALISI COMPARATA DELLA GIURISPRUDENZA ITALIANA}

\author{
LAURA VAGNI \\ Professor of Private Comparative Law \\ University of Macerata, Italy \\ ORCID: 0000-0001-6515-763X
}

Recibido: 22.11.2020 / Aceptado: 18.12.2020

DOI: https://doi.org/10.20318/cdt.2021.5975

\begin{abstract}
In the English system, the doctrine of proprietary estoppel prevents a legal owner from acting in an unconscionable manner to the detriment of a reliable claimant. A proprietary estoppel could give rise to a proprietary right of the claimant. Italian law does not recognise a similar doctrine nor does Italian property law seem compatible with it. Nevertheless, in some recent cases, the courts protected the claimant's reasonable reliance, preventing the legal owner from acting in contradiction with his/her own previous conduct (according to the maxim venire contra factum proprium nemo potest). This paper analyses these judicial decisions, and evaluates when and how the claimant's reliance is protected.

Keywords: property rights, venire contra factum proprium nemo potest, detrimental reliance, equity, informal promises.

Riassunto: Nel diritto inglese, in base al proprietary estoppel, un soggetto che è stato indotto dal proprietario a confidare nel verificarsi di effetti costitutivi o traslativi della proprietà può, al ricorrere di determinate circostanze, agire in giudizio per l'attribuzione del diritto in via equitativa. La regola, com'è noto, non trova riconoscimento nel diritto italiano. In alcune recenti decisioni le Corti italiane, tuttavia, pur nel rispetto formale delle regole in materia di proprietà, hanno impedito al proprietario di esercitare facoltà e poteri dominicali in violazione delle aspettative dallo stesso ingenerate in un soggetto terzo. Il presente lavoro analizza questa giurisprudenza, con lo scopo di valutare se e con quali effetti sia tutelato l'affidamento del terzo.
\end{abstract}

Parole chiave: diritti reali, venire contra factum proprium nemo potest, affidamento, equità, promesse e patti informali.

Summary: I. A premise: the maxim venire contra factum proprium nemo potest. II. Ius tollendi and protection of detrimental reliance. III. Tacit renunciation to enforce a property right acquired by usucapion. IV. The promise to perform an informal fiduciary contract. V. The confirmation of oral wills or donations. VI. Unilateral promises, informal agreements, and reliance protection against unfair conduct: an Italian version of estoppel. 


\section{A premise: the maxim venire contra factum proprium nemo potest}

1. The maxim venire contra factum proprium nemo potest evokes a rule according to which the holder of a right is estopped from enforcing it against a defendant, in contradiction with a state of facts or a previous conduct of the holder on whom the defendant relied. The doctrine developed during the jus commune, on the basis of the interpretation of the Corpus Iuris Civilis by the Glossators and Commentators, and it shows some similarities with the equitable doctrine of estoppel ${ }^{1}$. Consequently, some authors trace the two doctrines back to a common origin ${ }^{2}$.

2. In the English system, the equitable doctrine of estoppel developed as a processual exception that a defendant could raise before the Court of Equity to prevent fraudulent actions by a plaintiff.

In modern times, equitable estoppel is also recognised as a substantive rule and it is used not only as a shield but also as a sword ${ }^{3}$. Thus, in some circumstances, estoppel is a source of rights and a person's reliance could constitute grounds for judicial action. Nowadays, the doctrine is applied to different ambits of the law and under different names. Indeed, many authors speak about estoppels instead of estoppel and they identify different rules among the many judicial applications of the doctrine ${ }^{4}$.

3. Estoppel becomes a 'proprietary' estoppel if the right or interest claimed, on the basis of a reliance, is proprietary, such as a right over land or in relation to chattels or referred to a chose in action. In such cases, Equity prevents a legal owner from acting in an unconscionable manner and from asserting his/her legal title against the claimant. The main requirements for the application of the doctrine are: a) the claimant must to the knowledge of the legal owner have acted in the belief that the claimant has obtained or will obtain an interest in the property; $b$ ) the claimant must have acted to his or her detriment in reliance on such a belief ${ }^{6}$. Finally, a state of reliance could lead, in some circumstances, to the acquisition of a proprietary interest by a non-titled person on the basis of proprietary estoppel.

4. In the civil law systems, the maxim venire contra factum proprium nemo potest has never seen a similar application; conversely, the rules developed during the jus commune, and expressed by the Latin maxim, were only partially accepted by the codifications of the XIX century.

During the last century and in the first half of the new century, in the Italian system, the maxim was rarely quoted in the courts' decisions ${ }^{7}$. In recent times, however, there has been increasing attention paid to the rule and the courts have started to quote it in several judgments relating to various fields such

${ }^{1}$ The first important study by modern scholars is the work of E. RIEZLER, Venire Contra Factum Proprium. Studien in roemischen, englischen und deutschen Zivilrecht, Leipzig, Duncker \& Humblot, 1912; in Italian cf. F. RANIERI, Alienatio Convalescit: contributo alla storia e alla dottrina della convalida nel diritto dell'Europa continentale, Milano, Giuffrè, 1974, passim.

${ }^{2}$ For the first references about the relationship between the maxim venire contra factum proprium nemo potest and the equitable doctrine of estoppel cf. Sir. E. CoKe, The First Part of the Laws of England, or, a Commentary upon Littleton, 11th ed., to which are annexed Old Tenures, and some notes and additions, London, 1719, sect. 667, who affirms: "Estoppe cometh of a French word estoupe, from whence the English word stopped". In modern time, cf. L. DíEz -PicAzo, La doctrina de los propios actos, Barcelona, Bosch, 1963, p. 63; J.H. Wigmore, Treatise on The Anglo-American System of Evidence in Trials at Common Law, Including the Statutes and the Judicial Decisions of All Jurisdictions of United States and Canada, $3^{\mathrm{d}} \mathrm{ed} ., \mathrm{New}$ York, Little, Brown \& Co., 1940, n. 1117 and n. 2426; v. M.R.T. MACNAIR, The Law of Proof in Early Modern Equity, Berlin, Duncker und Humblot, 1999, p. 131 ff., at 136-137.

${ }^{3}$ Sir W.S. Holdsworth, A History of English Law, IX, London, Methuen, 1936, p. 146, according to whom the doctrine developed from a rule of evidence to a presumption iuris et de iure about the existence of a right. For an analysis of the modern doctrine cf. E. CoOKe, The Modern Law of Estoppel, Oxford, Oxford University Press, 2000, passim.

${ }^{4}$ Snell's Equity, 34 ${ }^{\text {th }}$ ed., London, Sweet \& Maxwell, 2019, III, chapter 12, sec 1. Introduction.

${ }^{5}$ Cf. Yeoman's Row Management Ltd \& Anor v. Cobbe, [2008] UKHL 55, for Lord Scott. However, cf. Thorner v. Majors and others, [2009] UKHL 18. On proprietary estoppel cf. B. McFarLane, The Law of Proprietary Estoppel, Oxford, Oxford University Press, 2014; M. Pawlowski, The Doctrine of Proprietary Estoppel, London, Sweet \& Maxwell, 1996.

${ }^{6}$ Grant v. Edwards, [1986] Ch 638, at 656, where Lord Brown-Wilkinson draws a similarity between promissory and proprietary estoppel.

${ }^{7}$ Some scholars affirm the utility of the maxim but, at the same time, they underline the impossibility of translating the maxim into a general principle of Italian law, applicable to all matters. Cf. F. Astone, Venire contra factum proprium, Napoli, Jovene, 2006, pp. 237-238; F. FESTI, Il divieto di “Venire contro il fatto proprio”, Milano, Giuffrè, 2007, p. 23. 
as contract law, labour law and administrative law. Moreover, many decisions about the law of obligations underline a close relationship between the maxim venire contra factum and the principles of good faith and fair dealing (Arts. 1175 and 1375, Italian civil code) ${ }^{8}$.

The new judicial interpretation is part of a general trend of recognition of the prohibition of venire contra factum proprium by case law, at a European and international level ${ }^{9}$, as well as in the case law of some other European national systems ${ }^{10}$,

5. In this scenario, however, property law seems the least permeable ambit for the application of the rule, due to the difficulty of reconciling it with the nature of the right of property in civil law systems.

The property owner has an absolute and exclusive right and he/she may also act in a contradictory manner or simply be inactive. In other words, a property right, in the civil law tradition, attributes to the title-owner a wide discretion, according to which the owner could indulge in conduct that does not conform to commonly accepted moral and social rules or which could even be antithetical to the standards of conduct of society ${ }^{11}$. Consequently, acts or statements made by the title-owner, in the exercise of a property right, do not give rise to an obligation against third parties, except in the cases established by law.

6. In the Italian system, there are a set of principles and rules according to which the constitution, modification, extinction of a real right or the effects erga omnes depend on the respect of formal requirements, whereas a state of facts or informal acts have no legal relevance. They are, for example, the principle of numerus clausus of real rights, the requirement of written form for the transfer, modification or constitution of land rights (Art. 1350 Italian civil code), the formal requirement for the validity of donation (Art. 782 Italian civil code), the formality required for the registration of land titles and the regulation of the effects of registration.

7. Although the Italian system of property law does not contemplate any recognition of proprietary estoppel, in some recent judgments the courts have prevented the property owner, who had induced a third party to rely on an acquisition of a property interest, from exercising his/her right in violation of such expectations. This case law concerns various cases, sometimes even isolated judgments, where the courts, using different legal arguments, recognised the right of the property owner, but they estop its exercise in violation of a detrimental reliance by a third party.

This paper presents some examples of these judicial decisions, without any claim to completeness, in order to evaluate whether, and in what cases, judicial protection of a third party's reliance could limit the content of a property right or its exercise by the title-owner.

\section{Ius tollendi and protection of detrimental reliance}

8. In general terms, accession is a method of original acquisition of ownership through the incorporation of a lesser thing into a greater one, the owner of the greater thing acquiring title to the lesser thing which is incorporated.

Italian law accepts the principle of incorporation and regulates acquisition by accession at Arts. 934 and following of the civil code.

${ }^{8}$ Cf. C. Amato, Affidamento e responsabilità, Milano, Giuffrè, 2012, p. 105, however, who distinguishes between good faith and estoppel: good faith being a general clause whereas estoppel developed as an exceptional remedy, and it has conserved this feature also in modern times.

${ }^{9}$ For the first references Cf. P. Pinsolle, "Les applications du principe de l'interdiction de se contredire au détriment d'autrui en droit du commerce international", in M. Behar-Touchais (ed.), L'interdiction de se contredire au détriment d'autrui, Paris, Economica, 2001, p. $37 \mathrm{ff}$.

${ }^{10}$ In the French system, for example, cf. O. Hilled/M.N. Jobard-BACHelLier, "Les applications du principe [de l'interdiction de se contredire au détriment d'autrui] en droit du contentieux interne et international", in M. Behar-Touchais (ed.), L'interdiction de se contredire au détriment d'autrui, cit., p. 53.

${ }^{11}$ Cf. A. Gambaro, Il diritto di proprietà, Trattato di Diritto Civile e Commerciale, directed by A. Cicu/F. Messineo, vol. VIII, II, Milano, Giuffrè, 1995, p. 212. 
Art. 934 c.c., in particular, provides that any planting, structure or works existing upon land belong to the owner of the land, except in cases expressly regulated by legislation. In the absence of legal title, therefore, a landowner automatically acquires ownership of any structure, erected by a third party on his/her land. The acquisition is original and it does not depend on the will of the owner of the land.

9. The Italian civil code establishes some exceptions to this rule. So, Art. 936 c.c. provides that when a third party builds a structure on the land of a proprietary owner, with his/her own materials, the landowner has the right to retain it or to compel such a person to remove it (ius tollendi). However, the landowner cannot compel the third party to remove the building when the landowner was aware of it and he/she did not oppose such works, and "[...] the works were undertaken by the third party in good faith" (Art. 936, paragraph 4). Some authors interpret the provision as a codification of the prohibition of venire contra factum proprium ${ }^{12}$ : from this perspective, the third party is in good faith only in the case of innocent ignorance, due to an appearance made by the landowner or by a third person.

10. The parties may establish by contract some exceptions to the principle of accession, according to legislation. For example, the landowner may alienate a right of superficies (ius aedificandi) to another party, by formal contract.

11. Italian courts also recognise protection of informal bilateral contracts through which a titleowner alienates a ius aedificandi and undertakes to respect the building erected on his/her land by the other contractual party. In these cases, the landowner acquires by accession the building erected by the other party. However, the landowner is bound to respect the obligation arising from the contract between the parties. Thus, the right acquired by the builder is not a real right and it is not enforceable erga omnes.

12. In a recent decision, the Italian Court of Cassazione dealt with the question of the principle of accession to decide whether it is applicable to co-ownership of land ${ }^{13}$. The case concerned a controversy between two co-owners of a building over a plot of land: the Cà d'Oro company and Mr. P. The Company added a basement to the building at its own cost. P sued the Company by requesting the division of the co-owned land and building, but the defendant objected and asked the judge to declare its exclusive ownership of the basement. Indeed, the parties had established by informal agreement that the Company was the owner of the basement and Mr. P had assured the Company that he would recognise its exclusive property of the basement.

13. The Court of Appeal, deciding the case, recognised the Cà d'Oro's exclusive property right to the basement and stated that the principle of accession is not applicable to co-ownership. Indeed, accession is applicable only when a third party builds on another's land, whereas the co-owner builder was not a third person with respect to the title-owner of the land ${ }^{14}$. According to this thesis, the building on co-owned land falls under common ownership if it is erected in compliance with the law of co-ownership (Arts. 1100 c.c. and following). Conversely, a building that modifies the original designated use of the co-ownership and precludes or limits its use by another owner is illegal and the latter could insist on its removal, and sue the builder for damages.

14. The Court of Cassazione departed from the interpretation given by the Court of Appeal and stated that the principle of accession is also applicable to co-ownership. Indeed, accession does not require the builder to have no title to the land. Therefore, the law of co-ownership does not interfere with the application of accession and the other methods of original acquisition of property. The Court stated:

\footnotetext{
${ }^{12}$ In these terms A. Gambaro, Il diritto di proprietà, cit., p. 769.

${ }^{13}$ Cass. Civ., plenary session, 16-02-2018, n. 3873, Il Foro Italiano, 2018, 4, I, 1200, with comment by C. BonA, "Accessione, comunione e Verwirkung".

${ }^{14}$ For the first references cf. L. ToRmEN, "Accessione e alterità soggettiva tra proprietario e costruttore: il chiarimento delle Sezioni Unite”, La Nuova Giurisprudenza Civile Commentata, 2018, vol. 6, pp. 847-863 and judicial decisions quoted ivi.
} 
"In reality, the criticised case law, by excluding the application of the principle of accession in coownership cases and establishing the application of the rules provided by Articles 1100 civil code and subsequent articles, create, by case law, a new method of original acquisition of property, that is not based on legislation"15.

15. In conclusion, the building erected by $\mathrm{Ca}$ d'Oro on the co-owned land is incorporated by accession in the land and the landowners acquired it in common. The Court specified that Art. 936 c.c. is not applicable in such cases. Indeed, Art. 936 requires the presence of a third non-owner builder. Nevertheless, on the basis of the law of co-ownership, the Company was liable to $\mathrm{Mr}$. P for a violation in the use of the common land and, consequently, P could exercise his right to remove the building erected without his consent (ius tollendi).

The Court of Cassazione recognised this right to $\mathrm{P}$, but it added that the exercise of ius tollendi needs to comply with the principles of tolerance, good faith and protection of reliance ${ }^{16}$. Therefore, the judge has to distinguish between the case where the builder erected the structure notwithstanding the co-owner's prohibition and the case where the co-owner gave his/her implicit consent or tolerated the building. In the first hypothesis, the co-owner of the land may exercise ius tollendi, whereas in the second he/she is estopped from removing the building in order to protect the reliance of the builder ${ }^{17}$.

For the same reason - the Court argued - even bare tolerance (that is the absence of any reaction by the owner who knew the building, for a reasonable period of time) prevents the owner from exercising ius tollendi ${ }^{18}$.

16. Finally, the law of co-ownership, interpreted according to the principle of good faith and protection of reliance, leads to the same effects as the application of Art. 936 civil code. Along these lines, the Court did not recognise a real right to the builder; in any case, it protected the builder's interest to maintain the building on the land, thus preventing the co-owner from profiting from the builder's reliance.

\section{Tacit renunciation of enforcing a property right acquired by usucapion}

17. In Italian law, the renunciation of a real right requires written form for it to be valid (Art. 1350 civil code).

18. Most Italian scholars sustain that the original acquisition by usucapion is automatic and the adverse possessor acquires a real right when all the requirements provided by the law are satisfied. Indeed, the judgment of a court that recognises acquisition by usucapion has a declarative value: the judge ascertains that the acquisition of a real right has taken place on the basis of continuous possession for a legally established period ${ }^{19}$. Along these lines, the renunciation of a real right acquired by usucapion should be written in order to be valid ${ }^{20}$.

\footnotetext{
${ }^{15}$ Cass. Civ., plenary session, 16-02-2018, n. 3873, cit.: "Il vero è che, nella sostanza, la giurisprudenza criticata, una volta esclusa l'applicabilità del principio di accessione in materia di comunione e ritenuta applicabile solo la disciplina di cui agli artt. 1100 e segg. cod. civ., è venuta a creare di fatto, per via pretoria, una nuova figura di 'acquisto a titolo originario' della proprietà, che non ha base legale" [my traslation].

${ }^{16}$ Ibidem.

${ }^{17}$ In these terms Court of Cassazione, ibidem.

${ }^{18}$ Cass. Civ., plenary session, 16-02-2018, n. 3873, cit.; cf. C. BonA, op. cit, according to which the Court evokes a rule similar to Verwirkung.

${ }^{19}$ Cf. S. Ruperto, "Usucapione (diritto vigente)", Enc. Dir., XLV, 1992, pp. 1022-1088, at 1046; U. Natoli, Il possesso, Milano, Giuffrè, 1992, p. 244 ff.; contra R. SACCO/R. CATERINA, Il possesso, Trattato di diritto civile e commerciale, directed by A. Cicu/F. Messineo, 2nd ed., vol. VII, Milano, Giuffrè, 2000, p. 508, who affirm: “[...] the person who possessed for twenty years is not the proprietary owner: he/she is a possessor or a owner depending on his/her own choice". Along these lines the possessor can renounce usucapion and usucapion cannot be declared by the judge ex officio.

${ }^{20}$ Contra R. SACCO/R. CATERINA, op. ult. cit., p. 509.
} 
19. Conversely, the case law establishes that acquisition by usucapion does not depend exclusively on the passage of time of possession. The original acquisition requires the adverse possessor to intend to profit from the favourable effects of the prolonged possession. Consequently, the acquisition by usucapion is enforced ope exceptionis, that is the person who wants to benefit from the acquisition has to take the matter to court.

20. A person in possession for the time required to acquire by usucapion may renounce the advantage of the favourable effects deriving from possession. The object of the renunciation is not a real right, but a personal right: the right to enforce the acquisition by usucapion.

21. According to the foregoing hypothesis, most case law affirms that a renunciation of usucapion does not need to be in written form. The renunciation could be oral or even tacit since it is not a renunciation of a real right ${ }^{21}$.

Tacit renunciation exists through actions by the entitled person that are incompatible with his/ her intention to sue the court for its declaration of usucapion. The person who renounced benefitting from the favourable effects of usucapion, expressly or tacitly, could not act in contradiction with his/her previous renunciation. Indeed, the registered owner can estop the possessor's claim.

22. In a recent case, the Court of Cassazione applied this doctrine and rejected the action of an adverse possessor who wanted to enforce a property right against the true owner, in contradiction with the previous tacit renunciation of the action, performed extrajudicially.

The parties to the controversy were a title-owner of a plot of land (a diocesan institute for the support of the clergy) and the adverse possessor of the same plot. Although the requirements for the acquisition by usucapion had matured, the possessor participated in a tender, launched by the true owner, and he made a proposal to purchase the land. The land was awarded to another offeror, so the adverse possessor sued the Court to enforce the acquisition of a property right by usucapion. The Court of Cassazione estopped the action of the plaintiff, stating that the conduct of the plaintiff and his participation in the tender were unequivocal expressions of his renunciation of the action.

23. The style of the Court's decisions does not allow a reader to understand the entire construction of the facts of the case, whereas the judgments of the Tribunali present a more detailed description of the facts. In fact, from the decision of the Tribunale of Camerino, in the first instance, it emerges that the adverse possessor had acted in a fraudulent way to the detriment of the registered owner. The adverse possessor raised the offer more than once during the tender. The Tribunale observed that the conduct of the possessor was "incomprehensible" as he wanted to purchase a property that "was already his own"22.

The possessor, "who was certainly not an unprepared person" ${ }^{23}$, did not inform the true owner about the usucapion and he preferred to participate in the tender. Then, the adverse possessor sued the registered owner in order to enforce the right of property originally acquired one year after the acquisition of the land by a third purchaser. This strategy had the aim of preventing the registered owner, made aware of the adverse possession, from interrupting the passage of the time for usucapion through an act of recognition of his title to the land. The Judge considered the possessor's conduct to be unfair because the latter knew that an act of recognition by the owner requires the owner's knowledge of adverse possession to be valid. So the adverse possessor was artfully silent.

24. In another case, the Court of Cassazione dealt with a controversy between the Minister of the Economy and some citizens ${ }^{24}$ about a plot of land acquired by the State through expropriation, in or-

\footnotetext{
${ }^{21}$ Ex multis, Cass. Civ., II, 30-05- 2016, n. 11158, www.dejure.it.

${ }^{22}$ Tribunale of Camerino, judgment, 7-11-2007, unreported.

${ }^{23}$ Ibidem: "Why did the possessor make an offer to acquire land already acquired by usucapion? Why was he silent about usucapion and why did he try to negotiate the purchase?".

${ }^{24}$ Cass. Civ., II, 19-01-2018, n. 1363, www.dejure.it.
} 
der to build a rainwater collection system. The work, however, never started and the citizens built houses on the land. The heirs of the builders, after many years, sued the Minister of the Economy and claimed recognition of their property rights on the plots of land, acquired by usucapion.

The Minister of the economy challenged the citizens' request to the competent public office for permission to build on the land. In doing so, they implicitly recognised the public ownership. Therefore, they renounced benefitting from the favourable effects of usucapion.

The Court of Cassazione, by adhering to this thesis, identified a tacit renunciation of the benefit from usucapion in the citizens' request for authorization to build.

25. In another similar case, the Court of Cassazione explained: "The renunciation, by an adverse possessor of a plot of land, of the favourable effects of the passage of time is not equivalent to a renunciation of an acquired real right [...]. Conversely, it leaves the right of the registered owner unaltered, as it amounts to a refusal to claim judicial protection for adverse possession, prolonged for the time established by law" 25 .

26. The same rule is applied to other rights in rem on immovable property, such as easements. So, a holder of a right of easement may renounce the enforcement of his/her right. For example, in a case decided by the Court of Cassazione ${ }^{26}$, the plaintiff $\mathrm{G}$ sued the neighbouring landowner in order to enforce a right of easement, acquired by usucapion. The defendant moved in opposition that $\mathrm{G}$ had acquired his plot of land from a diocesan Institute and, before the purchase, the Institute had renounced benefitting from usucapion in a written communication, delivered to the defendant. G did not know about the renunciation by the previous owner of the land and he argued that the renunciation was not opposable against him. Conversely, the Court of Cassazione stated: "[...] the written renunciation of the usucapion of an easement by the owner of the dominant tenement [...] is relevant ex se, and its effects do not depend on the communication of the renunciation to the purchaser of the dominant tenement or to the registration of the right" 27 .

27. Similar judicial decisions raised a wide debate among scholars, due to the difficulty of aligning the interpretation of case law to the legislation on usucapion, according to which original acquisition is based on possession (Art. 1158 c.c.). Then, the effects deriving from the renunciation of the enforcement of a real right give rise to a set of difficult questions. According to most case law, the renunciation of enforcement of usucapion is not opposable against a 'true' third party with respect to the possessor who matured the right. However, a universal successor and a purchaser from the possessor are not considered "third parties" by the courts ${ }^{28}$. As a result, the object of the renunciation is a personal right to judicial protection, but the renunciation has an external relevance since it is opposable against the purchasers from the possessor.

28. Case law regarding renunciation of enforcement of a property right acquired by usucapion is echoed in other judicial decisions, where the courts rejected the action of a plaintiff, raised in contradiction to his/her own previous conduct. In one case ${ }^{29}$, a Bank was the creditor of a company, and Mr. AG had provided a guarantee. The guarantor performed the obligation and wanted to take over the

\footnotetext{
${ }^{25}$ Cass. Civ., II, 10-04-2019, n. 10056, www.dejure.it: “[...] la rinuncia agli effetti positivi del decorso del tempo da parte del possessore di un bene immobile altrui non equivale alla rinuncia al diritto di proprietà già acquisito [...] ma conserva inalterato il diritto di proprietà del precedente titolare, attraverso il rifiuto di far valere la tutela giuridica concessa nei confronti del possesso ininterrotto protratto per il periodo di tempo previsto dalla legge" [my translation].

${ }^{26}$ Cass. Civ., II, 30-05-2016, n. 11158, cit., on the same issue v. the comment by S. NARDI, "Rinuncia all'usucapione - profili in tema di vicende possessorie, tra accessione e rinuncia all'usucapione della servitù", Giurisprudenza Italiana, vol. 3, 2017, pp. 615-622.

${ }^{27}$ Cass. Civ., II, 30-05-2016, n. 11158, cit.: “[...] la rinuncia per iscritto all’usucapione della servitù di passaggio fatta dal proprietario del fondo dominante [...] rileva di per sé, non potendo la sua efficacia negoziale essere fatta dipendere né dall'avvenuta comunicazione al successivo acquirente $[\ldots]$ né dall'osservanza dell'onere della trascrizione".

${ }^{28}$ In these terms Cass. Civ., II, 14-12-2018, n. 32390, www.dejure.it.

${ }^{29}$ Court of Appeal of Florence, 29-08-2016, n. 1370, www.dejure.it.
} 
credit against the debtor. According to Italian law, the guarantor, who performs the obligation of the debtor, has a right of subrogation to the mortgage (Art. 1203 c.c.). Art. 2843 c.c. provides that the subrogation is opposable to third parties after its annotation in the land registry. In this case, the guarantor waited three years before annotating the subrogation. In the meantime, the debtor asked the Bank to cancel the mortgage and the latter gave its consent. After that, the guarantor sued the Bank and the debtor, and he claimed payment of the debt. The Court of Appeal of Florence rejected the action stating: "[...] the unjustified omissive behaviour on the part of the guarantor [of annotation for three years] implied his assumption of the risk of cancellation of the mortgage by virtue of the full discharge of the original debt" ${ }^{\prime 3}$. The Court of Cassazione confirmed the decision ${ }^{31}$. The Court added: "The unjustified acquiescence, for a long time, could be potentially interpreted as an implicit renunciation to enforce the right of mortgage" 32 .

In conclusion, the debtor may estop the judicial action of the creditor, for the exercise of a right of mortgage, if the action is brought to challenge a state of acquiescence, protracted for a long time.

\section{The promise to perform an informal fiduciary contract}

29. In the Italian system, the transfer of rights on immovable properties needs to be in written form (Art. 1350 c.c.). The requirement of the written form constitutes a special rule and it applies to all contracts for the transfer of real rights on immovables or for contracts giving rise to an obligation to transfer real rights on immovables ${ }^{33}$. A case in point is the preliminary contract, regulated by Art. 1351 c.c., according to which the preliminary contract is void if it does not respect the formal legal requirement for the definitive contract to be valid.

30. Traditional case law establishes that Art. 1350 c.c. is applicable to a fiduciary agreement regarding an immovable property ${ }^{34}$. On the basis of the latter, a fiduciary is obliged to transfer an immovable property to a fiduciant, the property has been acquired thanks to the money of the latter. Therefore, an oral fiduciary agreement regarding an immovable property is void and the promise made by the fiduciary to transfer back the property right is unenforceable.

31. Nevertheless, a part of case law also ascribes legal effect to a unilateral promise by a fiduciary to transfer back a property right, made in execution of an informal fiduciary agreement between the parties.

32. This interpretation was followed by a decision of the Court of Cassazione in $2014^{35}$. The controversy was between spouses who had concluded an oral fiduciary contract. On the basis of the contract, the wife purchased four flats, with her husband's money, which she was obliged to be transferred back to her spouse on request. Some years later, the wife recognised, in a written declaration, that the immovable properties really belonged to her husband and she promised to transfer back the properties. The wife, however, did not keep her promise and the husband sued the court for the specific performance of his wife's obligation. The case was brought before the Court of Cassazione. The Court established that the informal fiduciary agreement and the unilateral promise by the wife constituted two parts of a single

\footnotetext{
${ }^{30}$ Ibidem, the Court of Appeal underlined that the creditor waited three years before annotating the subrogation: "[...] adottando, così, un ingiustificato comportamento omissivo che comportava (...) l'assunzione da parte del medesimo del rischio di cancellazione delle ipoteche in forza dell'estinzione totale del credito del creditore originario". [my translation].

${ }^{31}$ Cass. Civ., III, 09-05-2019, n. 12252, www.dejure.it.

${ }^{32}$ Ibidem: "[...] l'inerzia ingiustificata e protratta nel tempo, da parte di quest'ultimo, [può] essere 'potenzialmente interpretata e valutata alla stregua di una rinuncia implicita alla garanzia ipotecaria"”.

${ }^{33}$ Written form is required for the validity of a set of contracts, established by art. 1350 c.c. and by special legislation. Cf. recently Cass. Civ., II, 09-12-2019, n. 32108, www.dejure.it.

${ }^{34}$ Ex multis v. Cass. Civ., II, 18-10-1988, n. 5663, www.dejure.it; Cass. Civ., II, 29-05-1993, n. 6024, www.dejure.it.

${ }^{35}$ Cass. Civ., III, 15-05-2014, n. 10633, www.dejure.it.
} 
transaction, based on a fiduciary cause. Indeed, the declaration made by the wife was, partially, an act of recognition of her husband's right and it was, partially, a promise to transfer the properties acquired.

The Court stated: "The promise to transfer, based on an oral pactum fiducie, between the spouses, has its autonomous source of law in the written declaration of the wife [...], and it constitutes a unilateral recognition of the previous fiduciary contract [...], and, clearly expresses the present obligation of the wife" $" 36$.

In conclusion, the Court protected the reliance of the husband on his wife's promise by granting specific performance.

33. Some scholars have criticised the decision of the Court of Cassazione $e^{37}$, arguing that it contradicted some undisputed principles of Italian private law such as the requirement of the written form for the contract to be valid, which constitutes, modifies, extinguishes and transfers real rights on immovable properties, the principle of numerus clausus of real rights, the unenforceability of atypical promises to transfer a property right to someone else ${ }^{38}$.

34. In fact, the decision of the Court of Cassazione is not an isolated case, but it echoes other judicial decisions where the courts enforced a unilateral promise to transfer a real right to someone else, in order to protect the promisee's reliance. In such cases, the courts adapted the traditional interpretation of contract law to make it conform with the protection of reasonable reliance. For example, the courts interpreted the claim of the promisee for performance of the promisor's obligation as an acceptance; therefore they construed the promise as an offer and the judicial action as an acceptance, thus concluding a binding contract ${ }^{39}$.

35. The Court of Cassazione $e^{40}$, in the case mentioned above, recognised such an interpretation as artificial and it established that a unilateral promise "expressed clearly and intended as binding" is, in fact, binding.

36. More recently, the Court of Cassazione, sitting in plenary session, stated that informal fiduciary contracts are enforceable ${ }^{41}$. The case concerned the question of the validity of a unilateral promise through which a fiduciary is obliged to transfer back property rights to a fiduciant, acquired thanks to the money of the latter. The plenary session stated that a unilateral promise to perform an informal fiduciary agreement is enforceable: the judge may grant specific performance in the case of lack of performance by the promisor. This conclusion was achieved by comparing the fiduciary agreement with a mandate granted without representation. A fiduciary contract for the purchase of property rights on immovables does not have to be in writing for it to be valid. Indeed, a fiduciary contract, like a contract of mandate,

\footnotetext{
${ }^{36}$ Ibidem.

${ }^{37}$ A. Gentili, "La forma scritta nel patto fiduciario immobiliare", Corriere Giuridico, 2019, vol. 12, pp. 1475-1494.

${ }^{38}$ In Italian law, unilateral promises are enforceable only in the cases established by legislation (Art. 1987 c.c.). Some scholars, however, admit the enforceability of atypical unilateral promises. The main argument in favour of the thesis is based on the interpretation of Art. 1333 c.c. The article provides that an offer for the purpose of forming a contract that creates obligation only for the offeror is irrevocable as soon as it comes to the knowledge of the party to whom it is directed. Cf. ex multis G. Castiglia, "Promesse unilaterali atipiche", Riv. dir. com., 1983, I, p. 331 ff.; A. Graziani, Le promesse unilaterali, Trattato di diritto privato, directed by P. Rescigno, Torino, 1984, vol. 9, p. 629 ff., A. D'Angelo, Le promesse unilaterali, Il Codice civile commentato, directed by P. Schlesinger, Milano, 1996, p. 1 ff., in comparative perspective see G. MARINI, Promessa e affidamento nel diritto dei contratti, Napoli, Jovene, 1995, passim; P. PARDOLESI, Promissory estoppel: affidamento e vincolatività della promessa, Bari, Casucci, 2009, p. 144 ff.; and in English ID., Promissory estoppel, in PG. Monateri (ed.), Contract law, Cheltenhan, Elgar, 2017, p. 469 ff., at 496. Yet in the last century the thesis was accepted by part of the case law, see Cass Civ., II, 14-11-1994, n. 9562, in Giurisprudenza Italiana, 1995, I, p. 1920, with comment by A. Gianola, "Verso il riconoscimento della promessa atipica, informale, gratuita, ma interessata".

${ }^{39}$ Cass. Civ., II, 24-04-1990, n. 3440, www.dejure.it; Cass. Civ., II, 05-06-2003, n. 8983, www.dejure.it; Cass. Civ., II, 0104-2003, n. 4886, Corriere Giuridico, 2003, vol. 8, p. 1041 with comment by V. Mariconda, "Una decisione della Cassazione 'a critica libera' sulla rilevanza della intestazione fiduciaria di immobili”.

${ }^{40}$ Cass. Civ., III, 15-05-2014, n. 10633, www.dejure.it.

${ }^{41}$ Cass. Civ., plenary session, 06-03-2020, n. 6459, www.dejure.it.
} 
is an obligatory contract and is enforceable between the parties. The written promise by the fiduciary to transfer back the acquired properties is a promise to pay and its effect is to reverse the burden of proof: so, the presence of a fiduciary contract is presumed and the fiduciant is not required to give evidence of its conclusion (art. 1988 c.c.).

37. Finally, the Court recognises the validity of an oral fiduciary contract for the purchase of real rights over land. Such a contract gives rise to an obligation of the fiduciary, who must transfer back the property. A unilateral promise to transfer the property to the fiduciant, made by the fiduciary, is not the source of the obligation to transfer, as is the contract. The court may grant specific performance to enforce such a contract.

\section{Confirmation of oral wills or donations}

38. Italian law regulates the confirmation of void wills in Art. 590 c.c., according to which a person is prevented from challenging a will if, having been informed about the invalidity of the will, nonetheless he/she confirms the will or executes it, after the testator's death ${ }^{42}$. Confirmation of the will does not make it valid, but it simply precludes the person who confirmed from acting in contradiction to his/her previous confirmation. Art. 799 c.c., in the same way, provides confirmation of the invalid donation by the heirs or the purchasers from the donor.

39. These articles introduce an exception to the general prohibition to confirm void contracts or juridical acts and they find a precedent in Art. 1311 of the abrogated 1865 civil code. The latter stated that the confirmation, ratification or voluntary execution of a testamentary disposition (or of a donation) by the heirs, after the testator's death, implied their renunciation of challenging any defects of form or any other exception ${ }^{43}$.

40. When the code of 1865 was in force, scholars pointed out the difficulty of reconciling Art. 1311 with the principle according to which a void act or contract, due to a lack of formal elements, cannot be validated. So, some authors referred to a "mysterious riddle formulated by legislators" ${ }^{4}$ and they underlined the contradiction between the two rules ${ }^{45}$.

41. In reality, Art. 1311 was the legacy of a doctrine applied by the courts of France and of pre-unitary States during the $19^{\text {th }}$ century, according to which the heir could not venire contra factum proprium and he/she could not challenge a will in contradiction to his/her previous confirmation of the testator's dispositions ${ }^{46}$. In the $19^{\text {th }}$ century, the Court of Cassazione recognised the equitable nature of that rule and it established that: "Art. 1311 constitutes an exception to the system, suggested by equity"

42. The debate about the nature of the confirmation of wills and donations remained open even after the entry into force of the civil code of $1942^{48}$.

\footnotetext{
${ }^{42}$ For a general account, in comparative perspective, cf. A. Brawn, “Testamentary formality in Italy”, in K.G. Creid/M.G. Dewall/R. Zimmermann (eds.), Conparative succession law, vol. 1, testamentary formality, Oxford, Oxford University Press, 2011, p. 139.

${ }^{43}$ Art. 1311 civil code of 1865: "La conferma, ratifica o esecuzione volontaria di una donazione o disposizione testamentaria per parte degli eredi o aventi causa del testatore, dopo la morte di lui, include la loro rinuncia ad opporre i vizi delle forme e qualunque altra eccezione".

${ }^{44}$ L. BARAssi, "Nota a sentenza della Cassazione di Napoli, 14 dicembre 1908", Il Foro Italiano, 1909, c. 710.

${ }^{45}$ N. De Crescenzo, La dottrina della conferma e della ratifica degli atti nulli per difetto di forma, Napoli, Tipografia della Regia Università di Napoli, 1885, p. 2.

${ }^{46}$ Cf. F. Ranieri, Rinuncia tacita e Verwirkung, Padova, Cedam, 1971, p. 73 ff.

${ }^{47}$ Cass. Civ., 16-05-2941, n. 1476, Il Foro Italiano, 1941, I, c. 1036.

${ }^{48}$ V. L. Bigliazzi Geri, Successioni testamentarie, in Commentario del codice civile Scialoja-Branca, Bologna-Roma, 1993, p. 165 ff.; G. PASETti, La sanatoria per conferma del testamento e della donazione, Padova, Cedam, 1953, passim.
} 
One of the thorniest questions concerns the tacit confirmation of an oral will or donation by the heirs or the purchasers from the donor. Decisions by the courts on the matter are rare, but they sustain the application of Art. 590 c.c. and of Art. 799 c.c. in the case of an oral will or donation.

43. So, for example, Art. 590 c.c. was applied by the Tribunale of Naples in a decidedly singular case concerning the confirmation of a father's oral will by his two daughters ${ }^{49}$.

The facts of the case were as follows: in a family made up of a father, a mother and two daughters, the father was the owner of three flats and the mother of one flat. The father died intestate. The heirs, who wanted to carry out their father's wish to divide the entire assets of the family into equal parts between the daughters, decided to draw up a false will. The older daughter wrote the will, leaving two flats to herself and one flat to her sister. Then, the heirs (mother and daughters) decided, together, not to challenge the will, but they wrote a document in which the mother promised to bequeath her flat to her younger daughter, in order to settle scores between the sisters. However, the mother did not keep her word and after some years she sold the flat. Therefore, the younger daughter sued the mother and the sister, invoking the voidness of her father's will and claiming restitution of the assets corresponding to her legitimate portion.

44. The Court rejected the action of the plaintiff. In fact, the parties knew the apocryphal nature of the will, but they admitted full correspondence between the false will and the oral will expressed by the father, during his life. Moreover, both the sisters had executed the testamentary dispositions and they had registered the purchase of the flats by succession in the land registry. Thus - affirmed the Court they had tacitly confirmed the oral will of the father.

45. In a recent decision, the Court of Cassazione dealt with the issue of confirmation of an oral donation. The controversy concerned a promise made by a man before dying. This man decided to leave a significant sum of money to his partner, who had taken care of him during a serious illness in the last years of his life. So, the case was not about real rights on immovable properties; it does, however, give an important indication regarding the enforceability of bare promises of donation.

46. The facts were as follows: Mrs V sued the brothers of the deceased partner (the heirs), arguing that the partner had promised to donate the sum of 120,000 Euros to her and claiming performance of such a promise. In fact, the heirs paid part of the sum to the plaintiff, after the man's death, but then they refused to perform the other part.

47. The Court of Appeal of Turin ordered the heirs to perform the oral donation made by the de cuius during his life.

From the facts of the case, it emerges that on the evening of the donor's death, in the mortuary room, a cousin of the de cuius spoke to the heirs, and she told them that their dear departed brother had promised the sum of 120,000 Euros to Mrs V. The cousin had known about the promise from the donor himself and she begged the heirs to honour their deceased brother's promise. The heirs then commissioned a financial advisor to pay part of the sum to the plaintiff. After some time, the plaintiff asked the heir for payment of the residual sum. The heirs answered in a letter, stating: "We are under no obligation to pay you even the smallest amount, as our dear departed brother Giuseppe did not dispose in your favour $[\ldots]$ however, as we are people who keep our word, we reiterate that we shall keep our word to pay the sum, that we freely decided to pay to you, within one year of Giuseppe's death"50.

\footnotetext{
${ }^{49}$ Tribunale of Naples, 30-06-2009, Giurisprudenza di Merito, 2010, vol. 12, p. 3010 ff., with the comment of M. DI MARZIO, "Accordo tra coniugi sulla destinazione post mortem dei beni".

${ }^{50}$ Court of Appeal of Turin, 13-05-2013, unreported: "[...] non sussisteva, in capo nostro, alcun obbligo di riconoscerTi la benché minima somma, non avendo il, da noi compianto, Giuseppe lasciato alcuna disposizione in tal senso". Aggiungevano: "[...] essendo persone di parola non possiamo che ribadirTi che onoreremo [...] la nostra parola rimettendoti il saldo di quanto abbiamo voluto liberamente riconoscerti entro un anno dalla morte di Giuseppe".
} 
The Court of Appeal stated that "there was an oral agreement of donation" between the de cuius and Mrs V. The letter written by the heirs gave evidence of their knowledge of the voidness of the oral promise by the donor and their intention to confirm the donation.

48. The Court of Cassazione confirmed the decision of the Court of Appeal stating that Art. 799 c.c. was applicable to oral agreements of donation ${ }^{51}$.

49. The confirmation presumes the presence, at least, of an agreement (of donation) between the parties. Conversely, a bare promise to donate is not confirmable.

50. In this case the de cuius promised to donate rather than concluding an oral contract of donation, but the Court of Appeal qualified the facts as an agreement (consisting of a promise by the donor and a tacit acceptance by the promisee). The Court of Cassazione does not decide about the facts of a case. As a result, the determination of the facts by the Court of Appeal was decisive for the application of Art. 799 c.c. and for the success of the plaintiff.

\section{Unilateral promises, informal agreements, and reliance protection against unfair conduct: an Italian version of estoppel}

51. The judicial decisions analysed in the previous paragraphs regard different cases and rules, concerning the principle of accession, original acquisition by usucapion, succession law and obligatory contracts. The Italian courts solve these cases by applying various rules and remedies: renunciation, recognition of a right, confirmation of a void will or donation, and specific performance (Art. 2932 c.c.).

52. One important question is whether there is a fil rouge linking these judicial decisions.

From this perspective, one may generally observe that all these cases are characterised by the fact that the title-owner is estopped from asserting his/her property right before a court, in contradiction with his/her previous promise, conduct or even tolerance of a state of facts. Thus, the courts held that the declarations or the conduct of the title-owner constitute an unequivocal expression of his/her will, which is legally binding. Therefore, the obligation of the title-owner and the prohibition to venire contra factum proprium depend on the expression of his/her will ${ }^{52}$.

53. However, a careful reading of the facts and of the reasons for the judgments also suggests another explanation of these judicial decisions.

Thus, in the judgment of the Court of Cassazione concerning the exercise of ius tollendi mentioned above, the Court draws a similarity between implicit consent and a state of tolerance by the landowner, and it establishes: "[...] bare acquiescence prevents the exercise of the right by the title-owner" 53 . The Court adds that the exercise of a ius tollendi is to be read together with the principle of tolerance. In this way, the Court makes a shift from the will of the landowner (implicitly expressed) to the reliance of the third builder: acquiescence, prolonged for a long time, prevents the owner from exercising his/ her right because - the Court literally states - "[...] tolerance induces the builder to rely on the owner's implicit consent" ${ }^{54}$. What is important, then, is not so much the will of the landowner, but the reasonable understanding of the third builder, on the basis of tolerance by the landowner.

\footnotetext{
${ }^{51}$ Cass. Civ., II, 12-04-2018, n. 9091, www.dejure.it

${ }^{52}$ The theory of will still influences the interpretation of law in the Italian system and other civil law jurisdictions. The basic idea is that a person's will is the source of obligation and the law acts upon this will. On the issue cf. G. GoRLA, Il contratto, vol. I, Lineamenti generali, Milano, Giuffrè, 1955, p. 77.

${ }^{53}$ Cass. Civ., plenary session, 16-02-2018, n. 3873, cit.: “[...] per la medesima ragione anche la mera tolleranza [...] preclude l'esercizio del diritto (del proprietario)" [my traslation].

${ }^{54}$ Ibidem: "[...] fa sorgere l'affidamento del costruttore sul sopravvenuto consenso implicito".
} 
54. In the cases regarding the original acquisition by usucapion, likewise, the courts apply the institute of tacit renunciation or implicit renunciation to reject the action of an original purchaser who wants to enforce the right acquired by usucapion.

55. The interpretation of the intention of the original purchaser is a question of fact and the Court of Cassazione does not decide on the matter. The analysis of the judgments delivered by the Tribunali and the Courts of Appeal, therefore, is very important for understanding the circumstances, on the basis of which, a judge may identify a will to renounce enforcing a right ${ }^{55}$.

56. The investigation described in this paper shows some facts that are relevant to the judges of first and second instances. For example, the Tribunale of Camerino, in the decision on usucapion, identified the intention of the original purchaser to renounce the judicial action in his unfair conduct against the registered owner. In the decision, the Judge insisted on the presence of unfair behaviour by the adverse possessor, with the aim of misleading the title-owner. Thus, the attention of the Court was focused on the position of the owner and evaluated what he should have reasonably understood.

57. Gino Gorla, a true founding father of modern comparative law in Italy ${ }^{56}$, explained this mechanism very clearly in his works: "The legal obligation does not derive from actual will, but rather from what [the plaintiff] wanted, or better from a complex set of circumstances, including the reliance of the promisee" ${ }^{57}$.

58. A similar consideration may be made with regard to the aforementioned cases concerning the confirmation of oral wills or donations ${ }^{58}$. The effects of confirmation have been long debated by Italian scholars, some affirming that confirmation validates will or donation ${ }^{59}$, others establishing that confirmation is a renewal of the juridical act or contract ${ }^{60}$, others considering confirmation as a performance of a natural obligation ${ }^{61}$, others again arguing that confirmation has only procedural effects ${ }^{62}$.

59. The aim of this paper is not to analyse the different theses regarding confirmation. I simply wish to underline that the courts apply the rule of confirmation in order to protect innocent reliance by an untitled defendant, rather than to impose consistent conduct by a titled plaintiff. Along these lines, bare promises, conduct or declarations by the right holder have legal relevance because they "cause the untitled person to hope" ${ }^{63}$ rather than because they reveal the intention of the right holder to be legally

${ }^{55}$ Cf. G. GoRla, "Le raccolte di giurisprudenza e le tecniche di interpretazione delle sentenze", Diritto comparato e diritto comune europeo, Milano, Giuffrè, 1981, p. 301., according to whom the investigation of the concrete facts of the case is important to understand the decision of the judge. In the Italian system, however, reports often do not describe the facts of cases and the reasons for judgments are presented as an abstract rule, rather than as a concrete rule which is applicable to the case. On this issue there is extensive literature, in English cf. J.P. Dawson, The Oracles of the Law, Ann Arbor, The University of Michigan Press, 1968, p. 376 ff.; G. Gorla, "Civilian Judicial Decisions. An Historical Account of Italian Style”, Tulane Law Review, 1970, vol. 44, p. $470 \mathrm{ff}$.

${ }^{56}$ E. Grande, "Development of Comparative Law in Italy", in M. Reimann/R. Zimmermann (eds.), The Oxford Handbook of Comparative Law, 2d. ed., Oxford, Oxford University Press, 2019, ch. 4. The A. quotes the Cornell Common Core Project, see R. B. Schlesinger (ed.), Formation of contracts. A Study in the Common Core of Legal Systems, 1968.

${ }^{57}$ G. Gorla, Il contratto, cit., p. 79: "Non al volere è collegato dalla legge il vincolo, ma al voluto, e non a questo soltanto, ma ad una ben più complessa situazione, ivi compreso l'affidamento del promissario [...]" [my traslation].

${ }^{58}$ There is extensive bibliography on the issue, ex multis cf. G. BAtTista FerRI, "Convalida, conferma e sanatoria del negozio giuridico", in Dig. It, Disc. Priv., vol. III, Torino, 1989, p. 355 ff.

${ }^{59}$ Cf. G. PASETTI, op. cit., p. 53 ff.

${ }^{60}$ A. Rocco, "La convalescenza dei negozi giuridici e l'art. 137 cod. di comm.", Studi di diritto commerciale ed altri studi giuridici, Roma, Società editrice del Foro Italiano,1933, vol. I, p. 343 ff.

${ }^{61}$ Cf. E. FinzI, Studi sulle nullità del negozio giuridico, Bologna, Zanichelli, 1920, vol. 1, p. 15 ff.

${ }^{62}$ Cf. G. PAsetTI, ult. op. cit., p. 179; v. also F. GAzzoni, "Il negozio di conferma della donazione nulla e la sua forma", Rivista di Diritto Commerciale, 1968, p. 313 ff.

${ }^{63}$ In similar terms, L. Moccia, "Promessa e contratto (Spunti storico-comparativi)", Rivista di Diritto Civile, 1994, p. 851, who explains that the ambivalent relationship between promise and contract also determines an ambivalence in the meaning of promise (as se obligare or as fidem dare). 
bound. Mutatis mutandis, in the cases concerning informal fiduciary contracts, the courts protect the fiduciant's reliance by recognising the legal effect of the promise of the fiduciary.

60. Finally, conduct, declarations or even acquiescence or tolerance of the right holder, analysed against the background of the relationship between the parties and taking account of other circumstances, which indicate a reliance by the third party, constitute the basis of a contractual obligation.

61. One may ask whether the protection of the reliant third party may lead, in some circumstances, to recognising real effects deriving from the application of the principle of venire contra factum proprium nemo potest. It is well known that, in the common law tradition, and, in particular, in the English system, proprietary estoppel could also be the source of a property right or interest, protected by real actions. As already mentioned in the premise of this paper, the same effect is precluded in Italian law by a set of principles and rules, according to which, on the one hand, the property owner has discretion in the enjoyment of his/her right; on the other hand, the production of real effects derives only from the respect of the legally established requirements.

62. The courts apply these rules in the judgments that have been analysed. For example, in the case mentioned in paragraph two, the titled-owner is prevented from exercising the ius tollendi against the builder, but the purchaser from the title-owner is not. The builder cannot oppose any title against the latter. One may wonder if the purchaser from the titled-owner, who knew the building of the third before he/she bought and made acquiescence, could exercise the ius tollendi against the builder or, conversely, if the builder may oppose against the exercise of the ius tollendi.

63. A similar question arises with regard to the renunciation of usucapion enforcement. As already mentioned, in this case, the object of renunciation is the judicial action rather than the real right. For this reason, the renunciation could be oral or implicit in the behaviour of the right holder. Consequently, it is not opposable against third parties. Nevertheless, the renunciation may assume an external importance in some cases: indeed, the reasons of the registered owner and his/her purchasers will prevail over those of the adverse possessor (who renounced) and over those of his/her purchasers ${ }^{64}$.

64. In the case about the confirmation of an oral donation, analysed in paragraph five, the Court of Cassazione applied Art. 799 to a unilateral promise. In this way, a bare promise by the donor is confirmed and executed, in the absence of the formal requirement established by Italian law for a donation to be valid (art. 782 c.c.).

65. Finally, the cases regarding fiduciary contracts show that specific performance is also granted by the courts for the performance of an obligation to transfer a property right, arising from an informal fiduciary contract.

66. Trying to draw some conclusive remarks from the heterogeneous case law investigated, unilateral promises, informal agreements and unfair conduct inducing reliance are construed as contracts and they are legally binding. In these cases, the constitution or transfer of a property right does not take place, as the legal requirements are missing, and the contracts give rise to personal rights. In some cases, the courts grant specific performance to the enforcement of such personal rights. In some exceptional cases, the obligation imposed on the right holder, for the protection of the third party's reliance, is enforceable even against his/her purchasers. Anyway, the protection of reliance never constitutes grounds for a proprietary right or interest, opposable erga omnes.

\footnotetext{
${ }^{64}$ Cf. R. Sacco/R. Caterina, Il possesso, cit., p. 509 ff., who distinguish between a renunciation accompanied by the restitution of possession and a unaccompanied renunciation: in the later case, the renunciation has legal effect between the parties, whereas in the former case, it has an external effect and is irrevocable.
} 
67. The proprietary owner is theoretically free to act in contradiction with his/her previous behaviour. Nevertheless, the courts estop the owner from unfair judicial actions to the detriment of a reliant third party and they adapt the interpretation of legislation to what is fair and just, as required by the case. The maxim venire contra factum proprium nemo potest expresses an equitable principle that guides the judge when deciding a case: the legal basis of the judicial decision is legislation, but the maxim recalls the equitable reason that inspires the judicial decision. In so doing, the courts disseminate equity in the law of property. 